\title{
The unique electrical properties in an extracellular fluid of the mammalian cochlea; their functional roles, homeostatic processes, and pathological significance
}

\author{
Fumiaki Nin $^{1}$ - Takamasa Yoshida ${ }^{1,2,3} \cdot$ Seishiro Sawamura $^{1} \cdot$ Genki Ogata $^{1,2}$. \\ Takeru Ota ${ }^{1}$. Taiga Higuchi ${ }^{1}$ - Shingo Murakami ${ }^{4,5,6} \cdot$ Katsumi Doi $^{7}$. \\ Yoshihisa Kurachi $^{4,5} \cdot$ Hiroshi HIBINO ${ }^{1,2,8}$
}

Received: 27 July 2016/Accepted: 16 August 2016/Published online: 27 August 2016

(C) The Author(s) 2016. This article is published with open access at Springerlink.com

\begin{abstract}
The cochlea of the mammalian inner ear contains an endolymph that exhibits an endocochlear potential (EP) of $+80 \mathrm{mV}$ with a $\left[\mathrm{K}^{+}\right]$of $150 \mathrm{mM}$. This unusual extracellular solution is maintained by the cochlear lateral wall, a doublelayered epithelial-like tissue. Acoustic stimuli allow endolymphatic $\mathrm{K}^{+}$to enter sensory hair cells and excite them. The positive EP accelerates this $\mathrm{K}^{+}$influx, thereby sensitizing hearing. $\mathrm{K}^{+}$exits from hair cells and circulates back to the lateral wall, which unidirectionally transports $\mathrm{K}^{+}$to the endolymph. In vivo electrophysiological assays demonstrated that the EP stems primarily from two $\mathrm{K}^{+}$diffusion potentials yielded by $\left[\mathrm{K}^{+}\right]$gradients between intracellular and extracellular compartments in the lateral wall. Such gradients seem to be controlled by ion channels and transporters expressed in
\end{abstract}

Hiroshi HIBINO

hibinoh@med.niigata-u.ac.jp

1 Department of Molecular Physiology, Niigata University School of Medicine, 1-757 Asahimachi-dori, Chuo-ku, Niigata, Niigata 951-8510, Japan

2 Center for Transdisciplinary Research, Niigata University, Niigata 950-2181, Japan

3 Department of Otorhinolaryngology, Graduate School of Medical Sciences, Kyushu University, Fukuoka 812-8582, Japan

4 Division of Molecular and Cellular Pharmacology, Department of Pharmacology, Osaka University, Osaka 565-0871, Japan

5 Center for Advanced Medical Engineering and Informatics, Graduate School of Medicine, Osaka University, Osaka 565-0871, Japan

6 Department of Physiology, School of Medicine, Toho University, Tokyo 143-8540, Japan

7 Department of Otolaryngology, Kindai University Faculty of Medicine, Osaka 589-8511, Japan

8 AMED-CREST, AMED, Niigata, Japan particular membrane domains of the two layers. Analyses of human deafness genes and genetically modified mice suggested the contribution of these channels and transporters to $\mathrm{EP}$ and hearing. A computational model, which reconstitutes unidirectional $\mathrm{K}^{+}$transport by incorporating channels and transporters in the lateral wall and connects this transport to hair cell transcellular $\mathrm{K}^{+}$fluxes, simulates the circulation current flowing between the endolymph and the perilymph. In this model, modulation of the circulation current profile accounts for the processes leading to EP loss under pathological conditions. This article not only summarizes the unique physiological and molecular mechanisms underlying homeostasis of the EP and their pathological relevance but also describes the interplay between EP and circulation current.

Keywords Cochlea $\cdot$ Hearing $\cdot$ Endocochlear potential $\cdot$ Ion concentrations $\cdot \mathrm{K}+$ transport $\cdot$ Electrophysiology $\cdot$ Computer simulation

\section{Introduction}

The auditory system continuously receives sounds of different intensities and frequencies from the ambient and extracts information necessary for the organism. The cochlea of the inner ear, the peripheral organ for hearing, harbors sensory hair cells that transduce mechanical stimuli to electrical signals. In humans, the audible frequencies range from 20 to $20,000 \mathrm{~Hz}$, whereas the maximum hearing threshold is a trillionfold larger in acoustic power than the minimum threshold [44]. These striking profiles depend not only on the properties of hair cells but also on the ones of a unique extracellular solution that immerses them [14, 22, 36, 42, 109]. This solution is called "endolymph." 
The cochlea is filled with the following two different extracellular solutions: perilymph and endolymph. Textbooks for life science such as "Molecular Biology of the Cell" and "Principles of Neural Science" explain that, in general, extracellular solutions including blood plasma, interstitial fluid, and cerebrospinal fluid bear a $\left[\mathrm{K}^{+}\right]$of $5 \mathrm{mM}$ and a $\left[\mathrm{Na}^{+}\right]$of $150 \mathrm{mM}$ $[3,51]$. This ionic composition is conserved in the perilymph. On the other hand, the cochlear endolymph contains $150 \mathrm{mM}$ $\mathrm{K}^{+}$and $5 \mathrm{mM} \mathrm{Na}^{+}$(Fig. 1a) [91, 94]. Furthermore, this solution exhibits an endocochlear potential (EP) of $+80 \mathrm{mV}$ with respect to the perilymph $[5,107]$. Hair cells expose stereocilia extruded from their apical surface to the endolymph and bath their basolateral membranes in the perilymph. Acoustic stimuli open mechanoelectrical transduction (MET) channels at the top of the stereocilia, facilitating the entry of $\mathrm{K}^{+}$from the endolymph

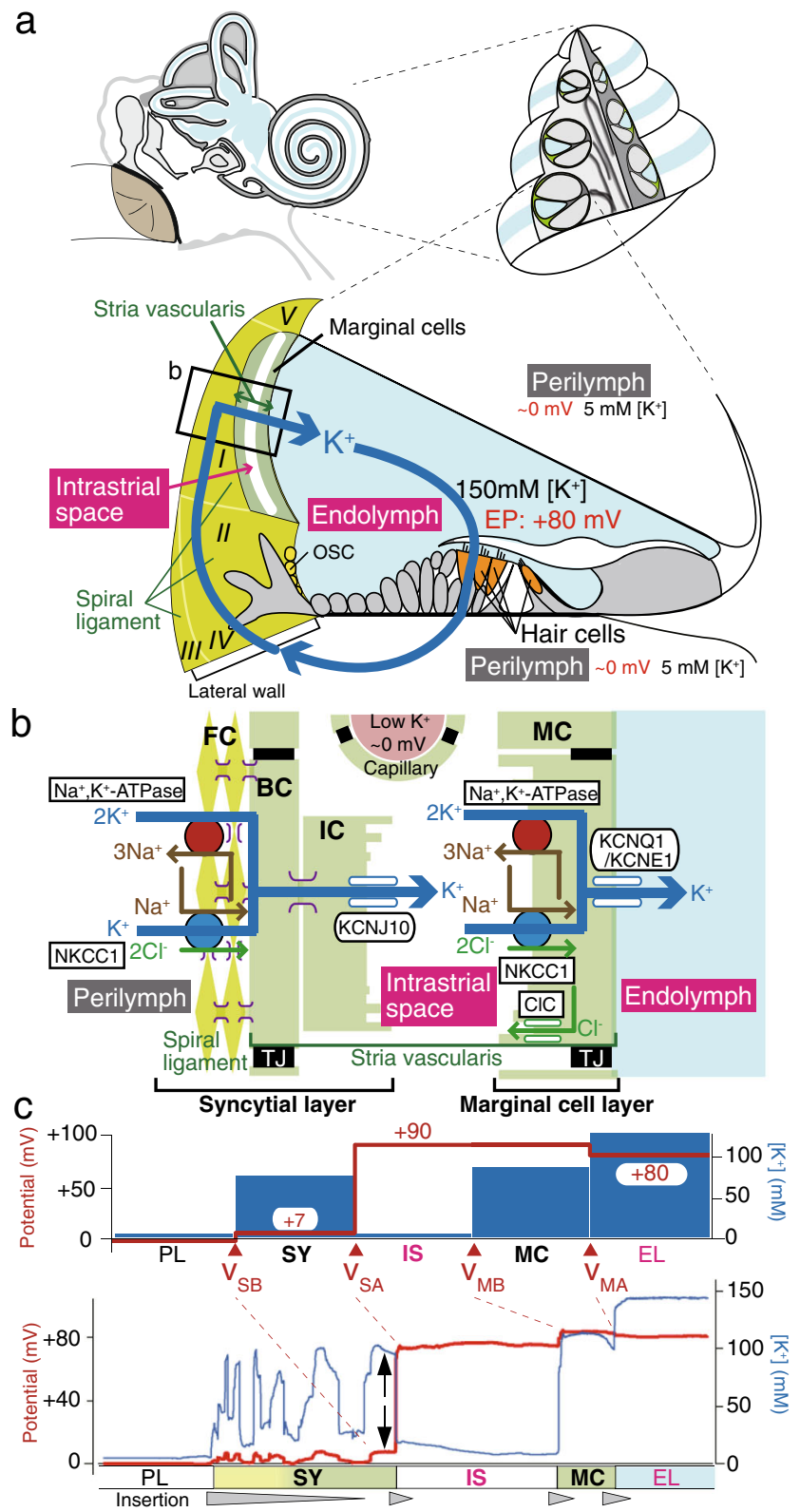

into hair cells. This $\mathrm{K}^{+}$influx depolarizes cells. Influx of $\mathrm{Ca}^{2+}$, which is also contained at a concentration of approximately $20 \mu \mathrm{M}$ in the endolymph, simultaneously occurs and tunes the hair cell functions involved in establishing the aforementioned dynamic ranges of audition [43]. The EP greatly enhances these ionic flows by increasing the driving force and thereby crucially contributes to the achievement of superior profiles of hearing [14, 22, 42, 46]. Loss of EP causes deafness $[42,59]$. After electrically exciting hair cells, $\mathrm{K}^{+}$is likely to exit from the basolateral membranes and reach the perilymph through $\mathrm{K}^{+}$channels (Fig. 1a) [20, 109].

The EP was measured for the first time in 1952 by Georg von Békésy, who won the Nobel Prize for the discovery of the physical mechanism of stimulation within the cochlea $[5$, 107]. Tasaki et al. (1959) found that the stria vascularis in the lateral cochlear wall is the source of the EP (Fig. 1a) [103]. Given that the stria harbors abundant vasculature, the maintenance of the EP was thought to need high energy. Indeed, anoxia causes a marked decrease in the EP [59, 63,

Fig. 1 Electrochemical profile of the cochlea. a Structure of the cochlea. The composition of the human ear and a cross section of the cochlea are illustrated in the upper left and right panels, respectively. The lower panel depicts the tissue and cellular components of the cochlea. The electrochemical properties of the endolymph and perilymph and the possible circulation of $\mathrm{K}^{+}$between the two are also shown. Note that the intrastrial space in the stria vascularis is emphasized with an expansion, although it is a narrow extracellular space of $15 \mathrm{~nm}$ in width. The locations of the five types of fibrocytes in the spiral ligament are indicated by roman numerals. The boxed region is enlarged in b. EP endocochlear potential, OSC outer sulcus cells. Reproduced and modified from [74]. b Cellular components of the lateral wall. Ion channels and transporters that are likely to play key roles in the maintenance of unidirectional $\mathrm{K}^{+}$transport across the lateral wall and endocochlear potential (EP) are shown in the upper panel. The lateral wall comprises the marginal cell layer and the syncytial layer that results from interconnections between fibrocytes (FCs) in the spiral ligament and the basal and intermediate cells (BC and IC, respectively) in the stria vascularis. Note that the basolateral and apical surfaces of the syncytial layer are provided primarily by fibrocytes and intermediate cells, respectively. $M C$ marginal cells, $N K C C 1 \mathrm{Na}^{+}, \mathrm{K}^{+}, 2 \mathrm{Cl}^{-}$cotransporter type $1, C l C \mathrm{ClC}-\mathrm{K} /$ barttin type $\mathrm{Cl}^{-}$channel, $T J$ tight junction. Reproduced and modified from [74]. c Potential and $\left[\mathrm{K}^{+}\right]$ properties of the lateral wall under physiological conditions. The top panel displays the properties averaged from multiple measurements. $v_{\mathrm{SB}}, v_{\mathrm{SA}}, v_{\mathrm{MB}}$, and $v_{\mathrm{MA}}$ indicate the membrane potentials across the basolateral and apical surfaces of the syncytial layer and the basolateral and apical surfaces of the marginal cell layer, respectively. Shown in the lower panel is a representative trace of the measurement in the cochlea of a live guinea pig. In this experiment, a microelectrode sensitive to potential (red) and $\left[\mathrm{K}^{+}\right]$(blue) was inserted from the perilymph (PL) into the endolymph (EL) across the lateral wall. Potentials in each compartment were measured with respect to the PL, which is defined to be $0 \mathrm{mV}$ in in vivo assays. Spike-like variations of $\left[\mathrm{K}^{+}\right]$represent the passage of numerous fibrocytes interconnected with each other by gap junctions. Within this region, the compartment located next to the intrastiral space (IS) likely represents the properties of the syncytial layer (SY) (i.e., $v_{\mathrm{SB}}$ and $\left[\mathrm{K}^{+}\right]$inside the syncytium; indicated by arrows) $[1,116]$. The wedges filled with gray below the lower panel indicate the periods during which the electrode was inserted toward the EL. $M C$ marginal cells. Reproduced and modified from [115] 
64]. Moreover, in vivo experiments showed that $\mathrm{K}^{+}$is actively supplied to the endolymph from the perilymph, rather than from the blood [60]. Substitution of a solution containing a low $\left[\mathrm{K}^{+}\right]$ with the perilymph markedly reduced the EP $[61,89]$. Accordingly, it was believed that the lateral wall, which consists primarily of the stria and the neighboring connective tissue, the spiral ligament, constitutes a route for the transport of $\mathrm{K}^{+}$from the perilymph to the endolymph and that this ionic flow is crucial for the maintenance of the unique properties of the endolymph (Fig. 1a, b) [55, 56, 108, 109]. Several physiological, histochemical, and molecular biology studies clarified the systems and elements necessary for $\mathrm{K}^{+}$transport and showed that their disruption results in hearing loss. This review focuses on recent understandings on the mechanisms underlying the homeostasis of the EP and their pathophysiological relevance.

\section{Structure and molecular architecture of the lateral cochlear wall}

In the lateral wall, the spiral ligament comprises five types of fibrocytes $(\mathrm{I} \sim \mathrm{V})$, all of which are bathed in the perilymph (Fig. 1a). The stria vascularis is made of three cell types, i.e., marginal, intermediate, and basal cells (Fig. 1b). Epithelial marginal cells and basal cells form monolayers with tight junctions and border the stria from the endolymph and the perilymph, respectively. Intermediate cells, basal cells, and fibrocytes are interconnected by gap junctions and thereby constitute a functional syncytial layer [55, 56, 97]. In this arrangement, it seems probable that the inner parts of these three cell types share the same electrochemical properties and that the basolateral and apical surfaces of the syncytial layer are provided primarily by fibrocytes and intermediate cells, respectively (Fig. 1b) [65, 92, 108]. Taking these considerations together, the lateral wall serves as a double-layered epithelial-like tissue consisting of the marginal cell and syncytial layers (Fig. 1b). Furthermore, endothelial cells of numerous capillaries that penetrate the two layers are also attached to each other by tight junctions $[47,57,58]$. In addition to this observation and to the fact that tight junction networks form in marginal and basal cells, electrically measured input resistance inside of the stria was found to be much higher than the one of the perilymph and the endolymph [74], indicating that this space is morphologically and electrically separated from the two lymphs and the blood. Another important characteristic is the complicated morphology of the intermediate cell membranes and basolateral membranes of marginal cells. These membrane compartments are highly invaginated, so that the extracellular space narrows down to $15 \mathrm{~nm}$ [41].

Classical pharmacological experiments using live animals characterized the channels and transporters expressed in the lateral wall and evaluated their possible physiological roles. Vascular and perilymphatic perfusion of ouabain, a blocker of
$\mathrm{Na}^{+}, \mathrm{K}^{+}$-ATPases, or loop diuretics such as furosemide and bumetanide, antagonists for the $\mathrm{Na}^{+}, \mathrm{K}^{+}, 2 \mathrm{Cl}^{-}$-cotransporter (NKCC), dramatically suppressed the EP, suggesting that these $\mathrm{K}^{+}$-uptake transporters act in the stria vascularis and spiral ligament and critically contribute to the EP [38, 39, $62,63,66,69,90,109]$. Loss of EP was also observed upon systemic injection of $\mathrm{Ba}^{2+}$ that inhibits $\mathrm{K}^{+}$channels, but it was not detected by perilymphatic application of this blocker [35, 70]. These results imply that the $\mathrm{K}^{+}$channels expressed in the stria vascularis play key roles in the formation of the EP.

From the 1990s, advanced molecular biology, histochemical, and electrophysiological techniques have unveiled the molecular constituents and cellular and subcellular localizations of channels, transporters, and other apparatuses. It is likely that tight junctions in marginal cell layer contain claudin-1, $-2,-3,-8,-9,-10,-12$, and -14 , and the ones in basal cells consist solely of claudin-11 [58]. Gap junctions included in the syncytial layer are constituted of connexin (Cx)-26, -29, -30 , and $-43[55,56,67,96,114,118]$. $\mathrm{Na}^{+}, \mathrm{K}^{+}$-ATPases in the stria vascularis are complexes of $\alpha_{1}$ and $\beta_{2}$ subunits and localize on the basolateral membranes of marginal cells, whereas those in the spiral ligament are composed of $\alpha_{1}$ and $\beta_{1}$ subunits and are expressed on the membranes of fibrocytes (Fig. 1b) $[19,73,81]$. The NKCC in the lateral wall is a type I cotransporter (NKCC1) and is present together with $\mathrm{Na}^{+}, \mathrm{K}^{+}$ATPases in marginal cells and type II, IV, and V fibrocytes (Fig. 1b) [19, 73]. Furthermore, type I and III fibrocytes bear the $\mathrm{K}^{+}, \mathrm{Cl}^{-}$-transporter $\mathrm{KCC} 3$ [11]. We previously demonstrated that an inwardly rectifying $\mathrm{K}^{+}$channel subunit $\mathrm{KCNJ} 10$ was expressed in the stria vascularis and responsible for $\mathrm{Ba}^{2+}$-sensitive $\mathrm{K}^{+}$channels involved in the generation of EP [35]. Subsequently, another research group found that this channel subunit is localized on the membrane of intermediate cells (Fig. 1b) [4, 98]. In addition, in the marginal cells, the KCNQ1 and KCNE1 subunits were found to assemble and form functional $\mathrm{I}_{\mathrm{KS}} \mathrm{K}^{+}$channels (KCNQ1/KCNE1) on the apical membrane as well as $\mathrm{Cl}^{-}$channels comprising the $\alpha$ subunit of $\mathrm{ClC}-\mathrm{Ka}$ or $\mathrm{ClC}-\mathrm{Kb}$ and the $\beta$ subunit of barttin (ClC-K/barttin) on the basolateral membrane (Fig. 1b) [27, 77, 82, 88, 101]. The channels and transporters described above are thought to directly or indirectly contribute to unidirectional $\mathrm{K}^{+}$transport across the lateral wall and to the EP formation. Moreover, patch-clamp assays of dissociated strial cells detected nonselective cation (NSC) channels on the basolateral and apical membranes of marginal cells [95, 101, 102]. Apical channels comprise the TRPM4 subunit [83, 113].

On the lateral wall, other ion channels and transporters may be expressed and involved in the control of unidirectional $\mathrm{K}^{+}$ transport. Candidates have been obtained by our recent mass spectrometry analysis of membrane proteins extracted from rat stria vascularis [105]. Of 3236 proteins detected in the analysis, 16 ion channels and 62 transporters had not yet been identified in the stria. These include the $\mathrm{K}^{+}$channels KCNJ13 
and $\mathrm{KCNN} 4$, as well as $\mathrm{K}^{+}, \mathrm{Cl}^{-}$-exchanger family proteins (KCCs). Although it must be carefully evaluated by histochemical approaches whether these $\mathrm{K}^{+}$transport molecules are expressed in the stria vascularis or their detection by mass spectrometry results from the contamination from other tissues, their identification might reveal novel mechanisms of homeostasis of the EP.

\section{Pathological significance of the molecules expressed in the lateral wall}

Intensive research endeavors for the last 20 years have identified that genetic ablations and mutations of ion transport proteins expressed in the stria vascularis result in hearing impairment in mice or humans, as summarized in Table 1. For instance, KCNE1- or KCNQ1-null mice show severe collapse of the scala media and deafness $[12,106]$, implying that $\mathrm{KCNQ} 1 / \mathrm{KCNE} 1 \mathrm{~K}^{+}$channels are crucial for driving $\mathrm{K}^{+}$transport and maintaining the endolymph. These mice also show vestibular disorder. Loss-of-function mutations of the gene encoding both subunits cause Jarvell and Lange-Nielsen syndrome, accompanied by hearing disorders and arrhythmia. Similar phenotypes were observed in animals lacking the NKCC1-gene [24, 26, 31]. Type 4 Bartter's syndrome, which is characterized by renal salt loss and hearing impairment, is induced by missense mutations in the amino-terminal region of the $\mathrm{Cl}^{-}$channel subunit barttin $[9,27]$. Knockout (KO) of this protein leads to loss of EP in mice [77]. KCNJ10-null mice display an $\sim 0 \mathrm{mV}$ EP with disruption of the structure of the scala media $[71,79]$. Mutations in the gene of this channel subunit underlie the EAST/SeSAME syndrome, characterized by deafness, epilepsy, ataxia, mental retardation, tubulopathy, and electrolyte imbalance [10, 85]. Interest information has been further provided by analyses of the $\mathrm{Na}^{+}, \mathrm{HCO}_{3}{ }^{-}$-exchanger SLC26A4, namely, pendrin, and the two-pore domain $\mathrm{K}^{+}\left(\mathrm{K}_{2 \mathrm{P}}\right)$ channel subunit KCNK5. These two proteins are expressed in outer sulcus cells [13, 28, 78], which are also constituents of the lateral wall and localized beside the fibrocytes (Fig. 1a). Mutations in the SLC26A4gene lead to Pendred syndrome, characterized by abnormal cochlear development, sensorineural hearing loss, and thyroid goiter [18, 49, 87]. Model mice of this disease display phenotypes of cochlear and vestibular dysfunctions with enlarged membranous labyrinths $[28,78]$. KCNK5-KO mice exhibit loss of several cell types including outer sulcus epithelial cells and hair cells [13]. In these two mouse lines, the EP was markedly impaired. Therefore, outer sulcus cells may serve as a platform for ion transport involved in the maintenance of the endolymph.

Table 1 Genes encoding lateral wall's ion transport proteins associated with hearing loss in human and mouse

\begin{tabular}{|c|c|c|c|c|}
\hline Molecules & Distribution & Human deafness types & Mouse phenotypes (other than deafness) & Reference \\
\hline $\begin{array}{l}\text { KCNE1 } \\
\quad \text { (Isk, min K) }\end{array}$ & $\mathrm{MC}$ & Jarvell and Lange-Nielsen syndrome & Collapse of SM and VES, balance disorder & [106] \\
\hline $\begin{array}{l}\text { KCNQ1 } \\
\text { (KvLQT1, } \\
\text { Kv7.1) }\end{array}$ & $\mathrm{MC}$ & Jarvell and Lange-Nielsen syndrome & Collapse of SM and VES, balance disorder & [12] \\
\hline KCNJ10 (Kir4.1) & IC & EAST syndrome, SeSAME syndrome & Collapse of SM, loss of EP $(\sim 0 \mathrm{mV})$ & {$[10,71,79,85]$} \\
\hline $\mathrm{KCNK} 5\left(\mathrm{~K}_{2 \mathrm{P}} 5.1\right)$ & OSC & - & $\begin{array}{l}\text { Loss of EP }(\sim+50 \mathrm{mV}) \text {, degeneration of hair } \\
\text { cells and spiral ganglions }\end{array}$ & {$[13]$} \\
\hline BSND (barttin) & $\mathrm{MC}$ & Type 4 Bartter's syndrome & Loss of EP $(\sim+17 \mathrm{mV})$ & {$[77]$} \\
\hline $\begin{array}{l}\mathrm{NKCC} 1 \\
\quad(\mathrm{SLC} 12 \mathrm{~A} 1)\end{array}$ & $\mathrm{MC}, \mathrm{FC}$ & - & Collapse of SM and VES, balance disorder & {$[24,26,31]$} \\
\hline $\begin{array}{l}\text { Pendrin } \\
\quad \text { (SLC26A4) }\end{array}$ & SPEC, OSC & Pendred syndrome, DFNB4 & Loss of EP $(\sim 0 \mathrm{mV})$ & {$[2,29,30,111]$} \\
\hline SLC22A4 & StE & DFNB60 & - & {$[6]$} \\
\hline $\begin{array}{l}\text { KCC3 } \\
\quad \text { (SLC12A6) }\end{array}$ & FC & - & Degeneration of hair cells & [11] \\
\hline GJA1 (Cx43) & $\mathrm{FC}$ & AR-nonsydromic deafness & - & [68] \\
\hline GJB1 (Cx32) & $\mathrm{FC}$ & X-linked Charcot-Marie-Tooth and deafness & - & [93] \\
\hline GJB2 (Cx26) & $\mathrm{FC}$ & $\begin{array}{l}\text { DFNB1, DFNA3A, hereditary palmoplantar } \\
\text { keratoderma with deafness }\end{array}$ & $\begin{array}{l}\text { Loss of EP }(\sim+50 \mathrm{mV}) \text {, degeneration of } \\
\quad \text { hair cells }\end{array}$ & {$[16,25,54,117,119]$} \\
\hline GJB3 (Cx31) & $\mathrm{FC}$ & DFNA2, AR-nonsyndromic deafness & - & [112] \\
\hline GJB6 (Cx30) & $\mathrm{FC}$ & DFNA3B & $\begin{array}{l}\text { Loss of EP }(\sim+3 \mathrm{mV}) \text {, degeneration of hair } \\
\text { cells }\end{array}$ & {$[34,104]$} \\
\hline Panx1 & $\mathrm{FC}, \mathrm{OSC}$ & - & Loss of EP $(\sim+60 \mathrm{mV})$ & {$[15]$} \\
\hline
\end{tabular}

$E P$ endocochlear potential, $S M$ scala media, $V E S$ vestibular endolymphatic space, $F C s$ fibrocytes, $B C s$ basal cells, $I C s$ intermediate cells, $M C s$ marginal cells, OSCs outer sulcus cells, SPECs spiral prominence epithelial cells, StE strial endothelium, DFNA the locus for autosomal dominant nonsyndromic deafness, $D F N B$ the locus for autosomal recessive nonsyndromic deafness, $A R$ autosomal recessive 
KO mice lacking any of the $\mathrm{Cx} 26,30$, and 43 subunits show hearing loss, suggesting the importance of ion transport through the connexin network in the lateral wall $[7,8,17,16$, $23,32,50,52,86,104]$. Finally, disruption of the claudin-11gene results in deafness accompanied by a severe decrease in EP to $\sim+30 \mathrm{mV}[33,57]$, and it highlights a crucial role for the barrier functions provided by tight junctions of basal cells in the stria vascularis.

\section{Mechanisms underlying the formation of the EP}

Along the identification of the molecular elements that contribute to the EP, the mechanisms underlying this process have been analyzed step by step. Pivotal observations were provided by in vivo electrophysiological experiments performed approximately 30 years ago. Salt et al. inserted a double-barreled $\mathrm{K}^{+}$-selective microelectrode, which can simultaneously measure the potential and $\left[\mathrm{K}^{+}\right]$, from the perilymph toward the endolymph across the lateral wall in live guinea pigs [84]. In the stria vascularis, after detecting a cellular compartment exhibiting a high $\left[\mathrm{K}^{+}\right]$, they found a unique extracellular space called "intrastrial space (IS)" that showed a highly positive potential similar to the EP and a low $\left[\mathrm{K}^{+}\right]$as observed in the perilymph. On the basis of these measurements, they assumed that (1) the cellular compartment close to the IS consisted of basal cells; (2) the IS potential (ISP) was primarily responsible for the EP and formed mainly by $\mathrm{K}^{+}$diffusion potential, i.e., $\mathrm{K}^{+}$equilibrium potential $\left(E_{K}\right)$; and (3) this diffusion potential resulted from high $\mathrm{K}^{+}$permeability on the apical surfaces of basal cells. The electrochemical properties of the IS were also confirmed by another report [45]. Later on, patch-clamp and immunohistochemical experiments demonstrated that $\mathrm{K}^{+}$permeability dominated the membranes of intermediate cells, as it emerged from KCNJ10 and other $\mathrm{K}^{+}$channels (Fig. 1b) [4, 100]. According to the aforementioned histological studies [41], the IS corresponds to the 15-nm extracellular space primarily surrounded by invaginated membranes of intermediate and marginal cells (Fig. 1b) [84].

By incorporating these observations, the "two-cell model" and the "five-compartment model" have been proposed to explain the generation of the EP [84, 108]. In this model, the EP represents a potential difference across the lateral wall composed of two layers,

$\mathrm{EP}=v_{\mathrm{SB}}-v_{\mathrm{SA}}+v_{\mathrm{MB}}-v_{\mathrm{MA}}$

where $v_{\mathrm{SB}}$ and $v_{\mathrm{SA}}$ are the membrane potentials across the basolateral and apical surfaces of the syncytial layer, respectively, and $v_{\mathrm{MB}}$ and $v_{\mathrm{MA}}$ are the ones across the basolateral and apical surfaces of the marginal cell layer, respectively (Fig. 1b, c). Each membrane potential was relative to the neighboring extracellular solution, which was defined as $0 \mathrm{mV}$. Equation 1 indicates that the EP depends on the four membrane potentials provided by the two layers of the lateral wall. Given that $\mathrm{K}^{+}$ conductance governs the intermediate cell membranes that correspond to the apical surface of the syncytial layer [100], Eq. 1 can be described by the equation

$\mathrm{EP} \approx v_{\mathrm{SB}}-\frac{\mathrm{RT}}{F} \ln \left(\frac{\left[\mathrm{K}^{+}\right]_{\mathrm{IS}}}{\left[\mathrm{K}^{+}\right]_{\mathrm{SY}}}\right)+v_{\mathrm{MB}}-v_{\mathrm{MA}}$.

In this scenario, the ISP is equivalent to the transepithelial voltage across the syncytial layer,

$\mathrm{ISP}=v_{\mathrm{SB}}-v_{\mathrm{SA}} \approx v_{\mathrm{SB}}-\frac{\mathrm{RT}}{F} \ln \left(\frac{\left[\mathrm{K}^{+}\right]_{\mathrm{IS}}}{\left[\mathrm{K}^{+}\right]_{\mathrm{SY}}}\right)$.

According to patch-clamp analyses and in vivo experiments $[72,84,99], v_{\mathrm{SB}}, v_{\mathrm{MB}}$, and $v_{\mathrm{MA}}$ were estimated to be small of $<10 \mathrm{mV}$ [100]. Therefore, it was assumed that the values of $-v_{\mathrm{SA}}$, ISP, and EP are approximately equal to each other (Eqs. 2 and 3). This relationship can be described as follows [100]:

$\mathrm{EP} \approx-\frac{\mathrm{RT}}{F} \ln \left(\frac{\left[\mathrm{K}^{+}\right]_{\mathrm{IS}}}{\left[\mathrm{K}^{+}\right]_{\mathrm{SY}}}\right) \approx \mathrm{ISP}$,

where $\left[\mathrm{K}^{+}\right]_{\mathrm{IS}}$ and $\left[\mathrm{K}^{+}\right]_{\mathrm{SY}}$ are the $\left[\mathrm{K}^{+}\right]$in the IS and inside the syncytial layer, respectively. We assayed the lateral wall of live guinea pigs with double-barreled $\mathrm{K}^{+}$-selective microelectrodes and confirmed the aforementioned potential and $\left[\mathrm{K}^{+}\right]$in the IS, as shown in Fig. 1c $[1,74,116]$. Our measurements also determined the properties of other compartments. First, the potential inside the syncytial layer, which is equivalent to $v_{\mathrm{SB}}$ in Eqs. $1-3$, is moderately positive $(\sim+7 \mathrm{mV})$, compared to the perilymph. Second, there is only a slight transepithelial voltage across the marginal cell layer (i.e., $v_{\mathrm{MB}}-v_{\mathrm{MA}}$; see Eqs. 1 and 2), and thereby, the ISP is similar to the EP. These observations reinforce the idea that the ISP represents the $\mathrm{K}^{+}$diffusion potential and dominates the $\mathrm{EP}$, as described by Eq. 5 .

Under physiological conditions, $\left[\mathrm{K}^{+}\right]_{\mathrm{SY}}$ greatly exceeds $\left[\mathrm{K}^{+}\right]_{\text {IS }}$ (Fig. 1c), providing a highly positive potential $(\sim+80 \mathrm{mV})$ for the ISP and EP (Eq. 4). On the other hand, when $\mathrm{Na}^{+}, \mathrm{K}^{+}$-ATPases or NKCC in the stria vascularis were impaired by anoxia, which would mimic ischemia, or by vascular perfusion of blockers, the EP dramatically reduced to -30 to $-40 \mathrm{mV}$ [59]. Under these conditions, it is plausible that $\left[\mathrm{K}^{+}\right]_{\mathrm{SY}}$ is smaller than $\left[\mathrm{K}^{+}\right]_{\mathrm{IS}}(\mathrm{Eq} .4)$ or that $v_{\mathrm{SB}}, v_{\mathrm{MB}}$, or $v_{\mathrm{MA}}$ is significantly modulated (Eq. 2). However, these alternations were not considered in the two-cell model or fivecompartment model. These issues were addressed by our fine in vivo measurements [74]. In the example shown in Fig. 2, a $\mathrm{K}^{+}$-selective microelectrode was held in the IS, while the other electrode was being inserted in the endolymph to continuously 


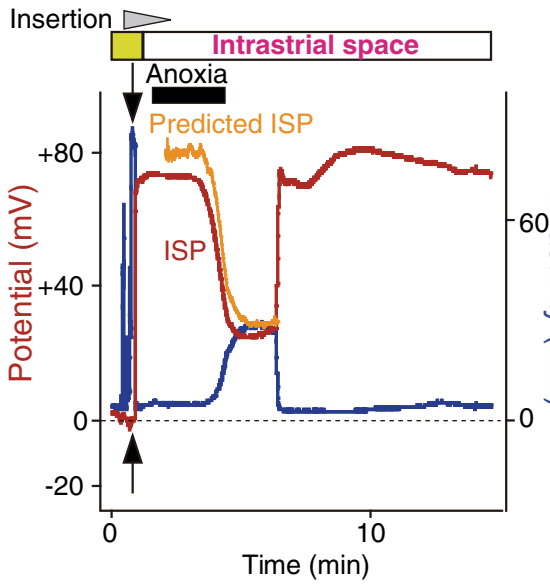

Fig. 2 Effects of anoxia on the electrochemical properties of IS and EP. In the left panel, a double-barreled microelectrode sensitive to potential (red) and $\mathrm{K}^{+}$(blue) was inserted in vivo from the perilymph (outset of the traces) toward the endolymph across the lateral wall of cochlea during the time interval marked with the wedge filled with gray (top of the panel). $\mathrm{K}^{+}$ concentration is indicated as $\mathrm{K}^{+}$activity $\left(a \mathrm{~K}^{+}\right)$. Location of the tips of the electrodes is shown by bars at the top of the panels. After passing the syncytial layer (green bar above the trace; see also Fig. 1c), the electrode encountered the intrastrial space (IS). The EP was simultaneously monitored with a different glass microelectrode placed in the

monitor the EP. Imposition of anoxia on the animal caused an increase in $\left[\mathrm{K}^{+}\right]_{\mathrm{IS}}$ and a decrease in ISP. Importantly, the ISP calculated from Eq. 3 with the measured $\left[\mathrm{K}^{+}\right]_{\mathrm{IS}},\left[\mathrm{K}^{+}\right]_{\mathrm{SY}}$, and $v_{\mathrm{SB}}$ (constant) was in agreement with the ISP directly recorded with the $\mathrm{K}^{+}$-selective microelectrode. This finding supports that the ISP stems primarily from the $\mathrm{K}^{+}$diffusion potential. On the other hand, the simultaneously measured EP was reduced more strongly than the ISP and reached a negative value. This indicates that anoxia can enlarge the transepithelial voltage across the marginal cell layer $\left(v_{\mathrm{MB}}-v_{\mathrm{MA}}\right)$ and that this property is involved in the reduction of the EP. To clarify the underlying mechanisms, we examined marginal cells and found that a large $\mathrm{K}^{+}$diffusion potential was induced on the apical surface of the marginal cell layer and it formed the difference between the EP and ISP (Figs. 3A, Ba). Under physiological conditions, the marginal cell $\mathrm{K}^{+}$diffusion potential, which is likely to emerge from KCNQ1/KCNE1 channels (Fig. 1b), is relatively small, because of the similarity between $\left[\mathrm{K}^{+}\right]$in the marginal cell layer $\left(\left[\mathrm{K}^{+}\right]_{\mathrm{MC}}\right)$ and $\left[\mathrm{K}^{+}\right]$in the endolymph $\left(\left[\mathrm{K}^{+}\right]_{\mathrm{EL}}\right)$ (Fig. 3A). Application of anoxia markedly decreased $\left[\mathrm{K}^{+}\right]_{\mathrm{MC}}$ with a minimal effect on $\left[\mathrm{K}^{+}\right]_{\mathrm{EL}}$, increasing the diffusion potential (Fig. 3Ba) [74]. Little change was detected in the membrane potential across the basolateral surface of the marginal cell layer $\left(v_{\mathrm{MB}}\right)$, in spite of the elevation of $\left[\mathrm{K}^{+}\right]_{\mathrm{IS}}$ and the reduction of $\left[\mathrm{K}^{+}\right]_{\mathrm{MC}}$. This experimental observation is reasonable, given that patchclamp analysis of isolated marginal cells detected abundant $\mathrm{Cl}^{-}$conductance but little $\mathrm{K}^{+}$conductance on their basolateral membranes [88]. Similar results were obtained when ouabain or the loop diuretic bumetanide was vascularly applied

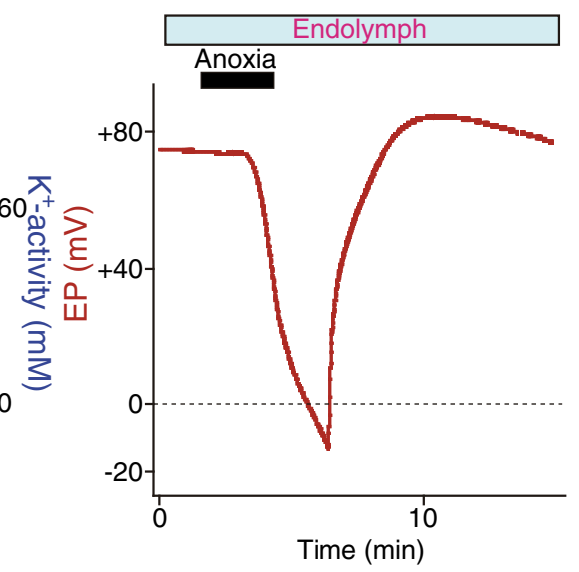

endolymph (right panel). Anoxia was imposed on the animal during the period indicated by bars filled with black above the traces. The values of the IS potential (ISP) were calculated from the measurements of $a \mathrm{~K}^{+}$in the IS $\left(a \mathrm{~K}^{+}{ }_{\text {IS }}\right)$ and $a \mathrm{~K}^{+}$and the potential of the syncytial layer $\left(a \mathrm{~K}^{+}{ }_{\mathrm{SY}}\right.$ and $v_{\mathrm{SB}}$, arrows in the left panel $)$ with the equation ISP $=v_{\mathrm{SB}}+\mathrm{RT} / \mathrm{F} \ln \left(a \mathrm{~K}^{+}{ }_{\mathrm{IS}} /\right.$ $a \mathrm{~K}^{+}{ }_{\mathrm{SY}}$ ). The predicted ISP (orange) was in agreement with the measured ISP (left panel). Note that the EP (right panel) was suppressed more strongly than the ISP (left panel) during anoxia. Reproduced and modified from [74]

(Fig. 3Ba) [74]. In summary, the EP primarily depends on two $\mathrm{K}^{+}$diffusion potentials on the apical surfaces of the syncytial and marginal cell layers,

$$
\begin{aligned}
\mathrm{EP} \approx v_{\mathrm{SB}}-\frac{\mathrm{RT}}{F} \ln \left(\frac{\left[\mathrm{K}^{+}\right]_{\mathrm{IS}}}{\left[\mathrm{K}^{+}\right]_{\mathrm{SY}}}\right)+v_{\mathrm{MB}}-\frac{\mathrm{RT}}{F} \ln \left(\frac{\left[\mathrm{K}^{+}\right]_{\mathrm{EL}}}{\left[\mathrm{K}^{+}\right]_{\mathrm{MC}}}\right) \\
\approx v_{\mathrm{SB}}-\frac{\mathrm{RT}}{F} \ln \left(\frac{\left[\mathrm{K}^{+}\right]_{\mathrm{IS}}}{\left[\mathrm{K}^{+}\right]_{\mathrm{SY}}}\right)-\frac{\mathrm{RT}}{F} \ln \left(\frac{\left[\mathrm{K}^{+}\right]_{\mathrm{EL}}}{\left[\mathrm{K}^{+}\right]_{\mathrm{MC}}}\right) .
\end{aligned}
$$

\section{Integration of circulation current into processes for formation of the EP by theoretical approaches}

Under physiological conditions, $\left[\mathrm{K}^{+}\right]_{\mathrm{IS}}$ is lower than $\left[\mathrm{K}^{+}\right]_{\mathrm{MC}}$ (Figs. 1c and 3A). However, blocking $\mathrm{Na}^{+}, \mathrm{K}^{+}$-ATPases or NKCC 1 in marginal cells, $\left[\mathrm{K}^{+}\right]_{\mathrm{IS}}$ and $\left[\mathrm{K}^{+}\right]_{\mathrm{MC}}$ gradually change, and finally, the former exceeds the latter (Fig. 3Ba) $[37,74]$. These $\left[\mathrm{K}^{+}\right]$dynamics, which underlie the reduction of ISP and EP, may derive from the modulation of currents through channels and transporters in the lateral wall. Nevertheless, such currents are neither measurable directly by in vivo electrophysiological approaches nor described in previous models and equations. Therefore, clarification of this issue requires theoretical approaches.

Each of the marginal cell and syncytial layers expresses particular $\mathrm{K}^{+}$channels or $\mathrm{K}^{+}$-uptake transporters on different surfaces (Fig. 1b). Assembly of these two layers in vivo must allow $\mathrm{K}^{+}$to unidirectionally move from the perilymph into the 


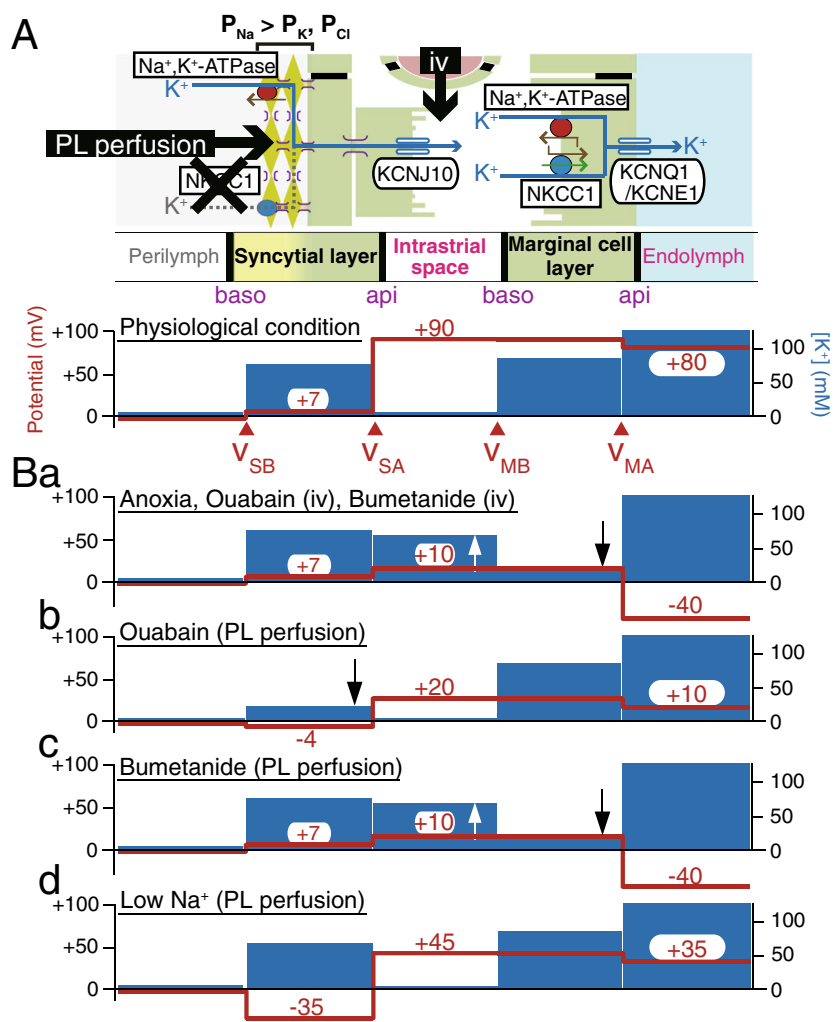

Fig. 3 Summary profiles of the electrochemical properties of the lateral wall. In A, the upper panel illustrates the cellular compartments of the lateral wall and the channels and transporters contributing to unidirectional $\mathrm{K}^{+}$transport and EP; the lower panel depicts the potential (red) and $\left[\mathrm{K}^{+}\right]$(blue) in intracellular and extracellular spaces under physiological conditions. Intravenous application (iv) of artificial solutions containing chemical compounds or modified ion compositions may primarily affect channels and transporters on the apical surface (api) of the syncytial layer and on the basolateral surface (baso) of the marginal cell layer, whereas perilymphatic (PL) perfusion is likely to strongly influence proteins on the basolateral surface of the syncytial layer. $v_{\mathrm{SB}}$, $v_{\mathrm{SA}}, v_{\mathrm{MB}}$, and $v_{\mathrm{MA}}$ indicate the membrane potentials across the basolateral and apical surfaces of the syncytial layer and across the basolateral and apical surfaces of the marginal cell layer, respectively. The panels in $\mathbf{B}$ display the potential and $\left[\mathrm{K}^{+}\right]$properties observed during anoxia, vascular perfusion of ouabain or bumetanide $(a)$, perilymphatic perfusion of ouabain $(b)$, bumetanide $(c)$, and a low $\mathrm{Na}^{+}$solution $(d)$. Observation of $b, c$, and $d$ implies that the $\mathrm{Na}^{+}, \mathrm{K}^{+}, 2 \mathrm{Cl}^{-}$-cotransporter type 1 (NKCC1) present on the basolateral surface of the syncytial layer is unlikely to transport $\mathrm{K}^{+}$and that this membrane domain is more permeable to $\mathrm{Na}^{+}$ than $\mathrm{K}^{+}$and $\mathrm{Cl}^{-}\left(P_{\mathrm{Na}}>P_{\mathrm{K}}, P_{\mathrm{Cl}}\right)$, as shown in the upper panel of $\mathbf{A}[115$, 116]. The upward and downward arrows indicate the increase and decrease of $\left[\mathrm{K}^{+}\right]$. Reproduced and modified from $[1,74,115,116]$

endolymph across the lateral wall. MET channels in hair cells are slightly open even in their resting state [80], so that in vivo $\mathrm{K}^{+}$constantly flows through cells. Taking these considerations together, it is plausible that, even without acoustic stimulation, $\mathrm{K}^{+}$is transported from the perilymph to the endolymph and then returns to the endolymph through the three layers in the cochlea, i.e., the syncytial, marginal cell, and hair cell layers (Fig. 1a). This "circulation current" composed of $\mathrm{K}^{+}[75]$, also referred to as " $\mathrm{K}^{+}$recycling" [55, 56, 109, 110], likely corresponds to an idling current in the electrical circuit. The existence of a circulation current was first proposed in Davis' battery theory [21], and it was validated by in vivo recording of the voltage gradient representing ion flows with a microelectrode in the perilymph [120]. The circulation current has been suggested to be involved in the maintenance of high potential and $\left[\mathrm{K}^{+}\right]$in the endolymph $[20,55,56,109$, 110].

The conditions of cells controlled by circulation current are different from the ones of cells isolated from the organism. When isolated cells are bathed in artificial extracellular solution filling an experimental chamber, their resting membrane potential (RMP) can be predicted with the Nernst or GoldmanHodgkin-Katz (GHK) equations. In this "equilibrium state," the total current across the cell membrane is zero. This is the principle of the two-cell model or five-compartment model (Eqs. 1-4) $[20,84,100]$ as well as the one of our earlier model (Eq. 5) [37, 74]. On the other hand, in vivo, the unidirectional circulation current is likely to constantly flow across the three layers even under physiological conditions. In this case, membrane potentials as well as ion concentrations in every cell are in the "steady state" and therefore constant. Based on this idea, we developed a computational model, the "NinHibino-Kurachi (NHK) model," to quantitatively describe the dynamics of the electrochemical properties of the cochlea (Fig. 4A) (for detailed equations, see [75]). In this model, the profile of each membrane is characterized by equivalent circuits of Hodgkin-Huxley-type equations that represent the function of channels and transporters. The circuits in six membrane domains were then connected in series to reconstitute the circulation current. In other words, the circulation current corresponds to the sum of the currents through all the channels and transporters in each membrane domain. This arrangement allows the circulation current to control membrane potentials as well as ion concentrations in the extracellular and intracellular compartments. In particular, the latter parameter is described by the following equation:

$$
\frac{d[X]}{d t}=\frac{I_{X, \text { in }}-I_{X, \text { out }}}{V \times F},
$$

where $[X]$ is the concentration of ion $\mathrm{X}, I_{X \text {,in }}$ is the inward current of $\mathrm{X}, I_{X \text {,out }}$ is the outward current of $\mathrm{X}, V$ is the volume of the extracellular or intracellular compartment, and $F$ is the Faraday constant. Each of $I_{X \text {,in }}$ and $I_{X \text {,out }}$ is the sum of the current passing through an X-permeable channel and the $\mathrm{X}$ flow through the transporter carrying $\mathrm{X}$ on the membrane. Note that $I_{X \text {,in }}$ and $I_{X \text {,out }}$ are components of the circulation current. Finally, the current passing through MET channels always equals the circulation current in the route across the hair cell layer. Thus, the amplitude of the circulation current depends on the potential difference across the apical surface of hair cells, i.e., the difference between the EP and the potential 

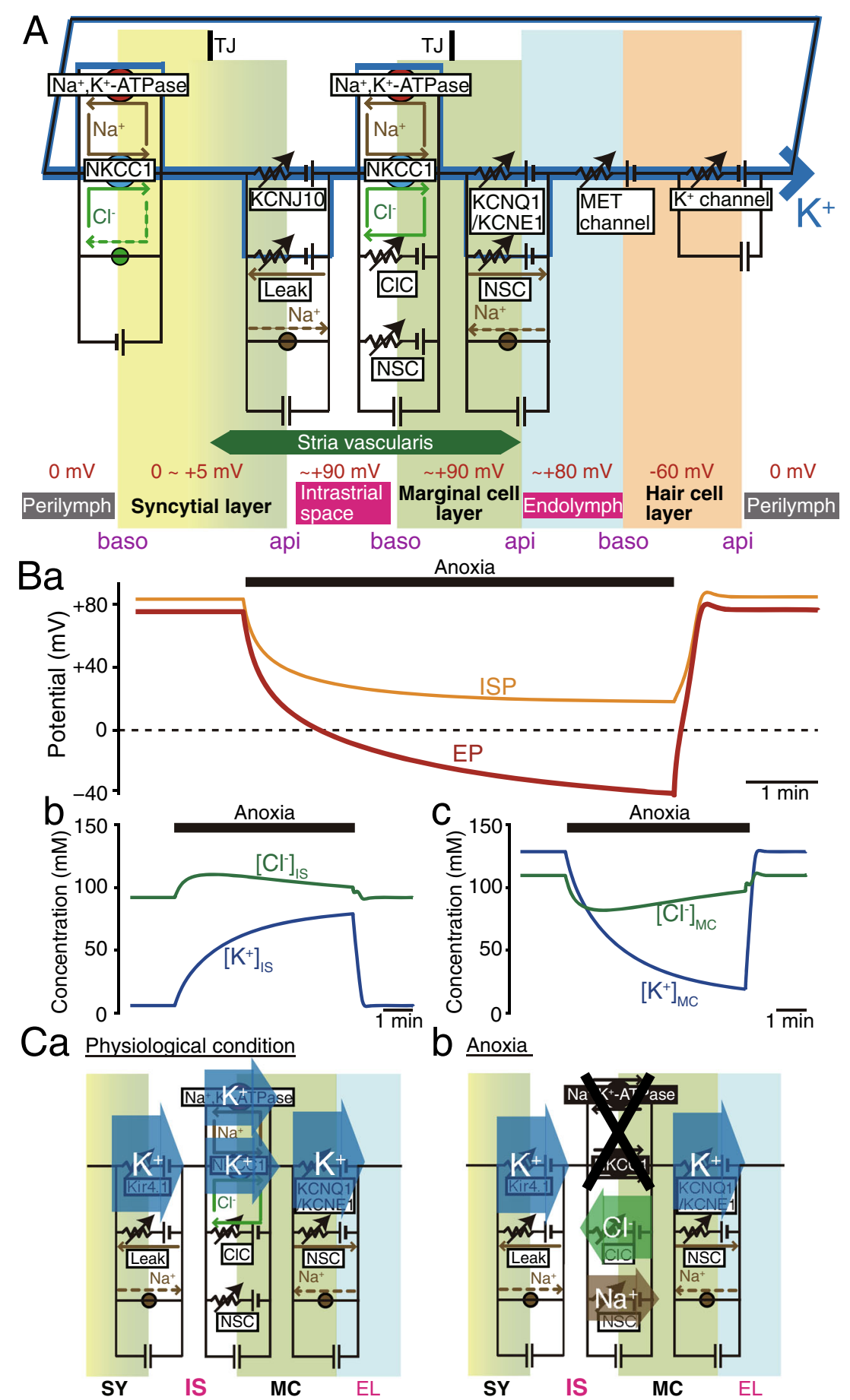

inside hair cells with respect to the perilymph. To summarize, under physiological conditions, the amplitude of the circulation current is constant and flows through every membrane of the three layers; $I_{X, \text { in }}$ is same as $I_{X \text {,out }}$ for every compartment (Eq. 6). This situation provides constant values for all of the ionic concentrations $(d[X] / d t=0)$, all of the membrane potentials, and the EP. However, when functions of channels or transporters are perturbed, the circulation current changes, modulating ionic concentrations and membrane potentials.
By using the NHK model, we simulated the electrochemical profile in the lateral wall and endolymph under physiological conditions and during anoxia that mimics ischemic conditions. Our in vivo experiments strongly suggest that imposition of anoxia on animals inhibited not only $\mathrm{Na}^{+}, \mathrm{K}^{+}$-ATPases but also NKCC on the basolateral surface of the marginal cell layer [75]. The measured behaviors for EP, ISP, $\left[\mathrm{K}^{+}\right]_{\mathrm{IS}}$, and $\left[\mathrm{K}^{+}\right]_{\mathrm{MC}}$ were highly reproducible in silico, when the activities of both of these $\mathrm{K}^{+}$-uptake transporters were reduced to $5 \%$ of the control (Fig. 4B). Simulated changes of 
4 Fig. 4 Computer simulation of electrochemical dynamics in the cochlea. A Key elements in the Nin-Hibino-Kurachi (NHK) model. The profile of each membrane is described by electrical circuits that represent the function of channels and transporters. The circuits in six membrane domains deriving from the syncytial, marginal cell, and hair cell layers were connected in series to allow the flow of circulation current, which is carried by $\mathrm{K}^{+}$under physiological conditions. NKCCl $\mathrm{Na}^{+}, \mathrm{K}^{+}, 2 \mathrm{Cl}^{-}$cotransporter type $1, C l C \mathrm{ClC}-\mathrm{K} /$ barttin type $\mathrm{Cl}^{-}$channel, NSC nonselective cation channel, $T J$ tight junction, $M E T$ mechanoelectrical transduction, baso basolateral, api apical. B Reproduction of electrochemical properties in the cochlea under physiological and anoxic conditions. Change of endocochlear potential (EP; $a$ ), IS potential (ISP; $a$ ), and ion concentrations in the IS $\left(b ;\left[\mathrm{K}^{+}\right]_{\mathrm{IS}}\right.$ and $\left.\left[\mathrm{Cl}^{-}\right]_{\mathrm{IS}}\right)$ and marginal cell layer $\left(c ;\left[\mathrm{K}^{+}\right]_{\mathrm{MC}}\right.$ and $\left.\left[\mathrm{Cl}^{-}\right]_{\mathrm{MC}}\right)$ were obtained by using the NHK model as reported in [75]; these results are in good agreement with in vivo measurements. Note that $\left[\mathrm{Cl}^{-}\right]$is moderately altered during anoxia ( $b$ and $c$ ). To simulate anoxic conditions, the activities of $\mathrm{Na}^{+}, \mathrm{K}^{+}$-ATPases and NKCC1 in the basolateral surface of the marginal cell layer were reduced to $5 \%$ of the control. C Profiles of the circulation current in the lateral wall. Net flow of each ion across the apical surface of the syncytial layer (SY), as well as through the basolateral and apical surfaces of the marginal cell layer (MC), are calculated and displayed in the panels. Under physiological conditions, the amplitude of $\mathrm{Na}^{+}$outflux through $\mathrm{Na}^{+}, \mathrm{K}^{+}$-ATPases is set to match the one of $\mathrm{Na}^{+}$influx through $\mathrm{NKCC1}$. $\mathrm{Cl}^{-}$transport by $\mathrm{NKCC} 1$ also cancels $\mathrm{Cl}^{-}$flow across the $\mathrm{ClC}-\mathrm{K} /$ barttin-type $\mathrm{Cl}^{-}$channel $(\mathrm{ClC})$. Due to these arrangements, the circulation current is composed purely of $\mathrm{K}^{+}(a)$. Under anoxic conditions $(b)$, the carrier of the circulation current in the basolateral surface of the marginal cell layer switches from $\mathrm{K}^{+}$to $\mathrm{Cl}^{-}$ and $\mathrm{Na}^{+}$that permeate the $\mathrm{ClC}$ and the nonselective cation channel (NSC), respectively. This change causes an increase in $\left[\mathrm{K}^{+}\right]_{\mathrm{IS}}$ and $\left[\mathrm{Cl}^{-}\right]_{\mathrm{IS}}$ and a decrease in $\left[\mathrm{K}^{+}\right]_{\mathrm{MC}}$ and $\left[\mathrm{Cl}^{-}\right]_{\mathrm{MC}}$, as shown in $\mathrm{B} b$ and $\mathrm{B} c$. IS intrastrial space, $E L$ endolymph. Reproduced and modified from [75]

current properties in the lateral wall are schematically illustrated in Fig. 4C [75]. Under physiological conditions, the circulation current is set to be purely made up of $\mathrm{K}^{+}$at any membrane domain (Fig. 4Ca). During anoxia, marginal cell transporters, which are blocked as mentioned above, can barely transport $\mathrm{K}^{+}$. Instead, the circulation current can pass as flows of $\mathrm{Cl}^{-}$and $\mathrm{Na}^{+}$through the $\mathrm{ClC}-\mathrm{K} /$ barttin and NSC channels, respectively; both of which are coexpressed with the two $\mathrm{K}^{+}$-uptake transporters. This indicates that the carrier of the circulation current can switch from $\mathrm{K}^{+}$to other ions on the basolateral surface of the marginal cell layer (Fig. $4 \mathrm{Cb}$ ). Consequently, $\mathrm{K}^{+}$influx exceeds $\mathrm{K}^{+}$efflux in the IS and vice versa in the marginal cell layer, causing an increase in $\left[\mathrm{K}^{+}\right]_{\mathrm{IS}}$ and a decrease in $\left[\mathrm{K}^{+}\right]_{\mathrm{MC}}$ (Fig. $4 \mathrm{Bb}$ and $\mathrm{Bc}$ ). In the late phase of anoxia, $\left[\mathrm{K}^{+}\right]_{\mathrm{IS}}$ significantly exceeds $\left[\mathrm{K}^{+}\right]_{\mathrm{MC}}(\mathrm{Fig}$. $3 \mathrm{Ba})$. These changes gradually affect membrane potentials and therefore reduce the ISP and EP (Fig. 4Ba). This EP impairment further results in the reduction of the amplitude of the circulation current.

\section{Profile of the basolateral surface of the syncytial layer}

The EP is determined by the potentials across the four membrane domains of the lateral wall, i.e., $v_{\mathrm{SB}}, v_{\mathrm{SA}}, v_{\mathrm{MB}}$, and $v_{\mathrm{MA}}$ (see Eqs. 1 and 5 and Fig. 3A, Ba). As described above, the marginal cell apical and basolateral surfaces as well as the syncytial layer apical surface, which corresponds to the intermediate cell membrane, have been so far considerably characterized by multiple approaches. However, little is known about the functional elements of the syncytial layer basolateral surface, formed primarily by fibrocytes of the spiral ligament [108].

Earlier studies demonstrated that perfusion of either ouabain or loop diuretics to the perilymph, in which fibrocytes are immersed, dramatically reduces the EP [69, 90]. Therefore, among several proteins expressed in fibrocytes, $\mathrm{Na}^{+}, \mathrm{K}^{+}$ATPases and NKCC seem to regulate electrochemical properties and $\mathrm{K}^{+}$transport in the lateral wall (Fig. 1b). This idea was tested in our in vivo experiments with $\mathrm{K}^{+}$-selective doublebarreled microelectrodes. Perilymphatic application of ouabain markedly decreased $\left[\mathrm{K}^{+}\right]_{\mathrm{SY}}$ with a minimum change of $\left[\mathrm{K}^{+}\right]_{\mathrm{IS}}[1]$ (Fig. 3Bb). As a consequence, the ISP and the EP declined (Eqs. 3 and 5). On the other hand, whereas bumetanide was perfused to the perilymph, $\left[\mathrm{K}^{+}\right]_{\mathrm{SY}}$ barely changed [116] (Fig. 3Bc). These results strongly suggest that, in the syncytial layer, $\mathrm{Na}^{+}, \mathrm{K}^{+}$-ATPases, but not $\mathrm{NKCC} 1$, functionally transport $\mathrm{K}^{+}$across the basolateral surface and maintain a high $\left[\mathrm{K}^{+}\right]_{\mathrm{SY}}$, essential for the large $\mathrm{K}^{+}$diffusion potential on the apical surface. Further analyses revealed that during perilymphatic perfusion of bumetanide, $\left[\mathrm{K}^{+}\right]_{\mathrm{IS}}$ increases and $\left[\mathrm{K}^{+}\right]_{\mathrm{MC}}$ decreases, as observed during vascular perfusion [116] (Fig. 3Bc). Therefore, this compound is likely to reach the NKCC1 on the basolateral surface of the marginal cell layer and impair the ISP and EP in processes similar to anoxia (see Eq. 5 and Fig. 3Ba).

It is surprising that in vivo and under physiological conditions, the basolateral surface of the syncytial layer exhibits a significantly positive potential $(\sim+7 \mathrm{mV})$ with respect to the perilymph $\left(v_{\mathrm{SB}}=\sim+7 \mathrm{mV}\right.$; Figs. 1c and 3A) [116], although in general, eukaryotic cells show a negative membrane potential at their resting state $[40,48,76]$. The positive RMP of the syncytial layer is critical for harvesting the $\mathrm{K}^{+}$diffusion potential on the apical surface to set the ISP and EP to a highly positive value (Eqs. 3 and 5), which is essential for hearing. As already mentioned, the syncytial basolateral surface is mainly provided by fibrocytes in the spiral ligament. In spite of the physiological importance of fibrocytes, the machineries underlying the establishment of this unique RMP have not yet been characterized. A major reason is likely to be the technical difficulty of patch-clamp assays conducted on fibrocytes tightly embedded in the extracellular matrix [53]. Our in vivo experiments with double-barreled $\mathrm{K}^{+}$-selective microelectrodes demonstrated that $v_{\mathrm{SB}}$ is remarkably hyperpolarized by perilymphatic perfusion of a solution with low $\left[\mathrm{Na}^{+}\right]$ (Fig. 3Bd), but it can only moderately be changed by a solution containing either high $\left[\mathrm{K}^{+}\right]$or low $\left[\mathrm{Cl}^{-}\right][115]$. These observations imply that the fibrocyte membrane is more permeable to $\mathrm{Na}^{+}$than to $\mathrm{K}^{+}$and $\mathrm{Cl}^{-}$(Fig. 3A), and this unusual 
profile is critically involved in establishment of the positive RMP under physiological conditions. During perfusion of the low- $\mathrm{Na}^{+}$solution, the ISP and EP were reduced to an extent similar to the alternation of $v_{\mathrm{SB}}$ (Fig. 3Bd), suggesting that this perturbation minimally affects the other membrane potentials in the lateral wall.

\section{Conclusions and perspectives}

As described above, various experimental techniques have demonstrated the molecular and physiological architectures that drive unidirectional $\mathrm{K}^{+}$transport across the lateral wall. This ionic flow is likely to be involved in maintaining the electrochemical properties of the syncytial and marginal cell layers and control the two $\mathrm{K}^{+}$diffusion potentials that form the EP. Correlation of the circulation current, which underlies $\mathrm{K}^{+}$ transport across the lateral wall, with the EP has also been demonstrated by theoretical approaches. In spite of these achievements, several issues remain to be clarified. First, it will be necessary to identify the proteins responsible for $\mathrm{Na}^{+}$ permeability, which plays a key role in maintaining the positive RMP in fibrocytes. A second interesting objective would be to identify the triggers that activate the fibrocyte NKCC1, a transporter that is likely to be silent under physiological conditions. The third open question is the process by which KCC3 in fibrocytes as well as SLC26A4 and KCNK5 in outer sulcus cells regulate the EP. Fourth, some of the channels and transporters in the lateral wall are expected to be functionally affected by $\mathrm{Ca}^{2+}$ or $\mathrm{H}^{+}$, but the relevance of these ions to the $\mathrm{EP}$ is still elusive. This issue may require detailed information on several $\mathrm{Ca}^{2+}$ or $\mathrm{H}^{+}$transporting molecules detected by our mass spectrometry experiments conducted on strial proteins [105]. All of these analyses will enable us to improve the NHK model and thereby more precisely describe how the EP and circulation current interplay with each other. A combination of improved computational models and conventional experimental approaches will help us to theoretically understand the reactions of the EP and the properties of the lateral wall in response to different acoustic stimuli, as well as to identify the pathophysiological mechanisms underlying hearing impairment observed in various human diseases and animal models. Further research will contribute to advance the auditory science and medical therapies for hearing disorders.

Acknowledgments This work was partially supported by the following research grants and funds: Grant-in-Aid for Scientific Research C 15K10770 (to KD); Grants-in-Aid for Young Scientists A 15H05683 (to FN); Grants-in-Aid for Scientific Research on Innovative Areas "HD Physiology" 25136704 (to FN) and 22136002 (to YK) from the Ministry of Education, Culture, Sports, Science, and Technology of Japan; AMEDCREST, AMED (to HH); a Grant for Promotion of Niigata University Research Projects 24A006 (to HH); grants from The Salt Science Research Foundation Nos. 1318 and 1549 (to FN); The Takeda Science
Foundation (to FN); The Uehara Memorial Foundation (to FN); and Astellas Foundation for Research on Metabolic Disorders (to FN).

\section{Compliance with ethical standards}

Ethical standards The experiments comply with the current laws of Japan.

Open Access This article is distributed under the terms of the Creative Commons Attribution 4.0 International License (http:// creativecommons.org/licenses/by/4.0/), which permits unrestricted use, distribution, and reproduction in any medium, provided you give appropriate credit to the original author(s) and the source, provide a link to the Creative Commons license, and indicate if changes were made.

\section{References}

1. Adachi N, Yoshida T, Nin F, et al. (2013) The mechanism underlying maintenance of the endocochlear potential by the $\mathrm{K}^{+}$transport system in fibrocytes of the inner ear. J Physiol 591:44594472. doi:10.1113/jphysiol.2013.258046

2. Albert S, Blons H, Jonard L, et al. (2006) SLC26A4 gene is frequently involved in nonsyndromic hearing impairment with enlarged vestibular aqueduct in Caucasian populations. Eur J Hum Genet 14:773-779. doi:10.1038/sj.ejhg.5201611

3. Alberts B, Johnson A, Lewis J, Raff M, Roberts K, Walter P (2014) Molecular biology of the cell, 5th edn. Newton press, New York

4. Ando M, Takeuchi S (1999) Immunological identification of an inward rectifier $\mathrm{K}^{+}$channel (Kir4.1) in the intermediate cell (melanocyte) of the cochlear stria vascularis of gerbils and rats. Cell Tissue Res 298:179-183

5. Bekesy G (1952) DC resting potentials inside the cochlear partition. J Acoust Soc Am 24:72-76

6. Ben Said M, Grati M, Ishimoto T, et al. (2016) A mutation in SLC22A4 encoding an organic cation transporter expressed in the cochlea strial endothelium causes human recessive nonsyndromic hearing loss DFNB60. Hum Genet 135:513-524. doi:10.1007/s00439-016-1657-7

7. Berger AC, Kelly JJ, Lajoie P, et al. (2014) Mutations in Cx30 that are linked to skin disease and non-syndromic hearing loss exhibit several distinct cellular pathologies. J Cell Sci 127:1751-1764. doi: $10.1242 /$ jes. 138230

8. Bicego M, Beltramello M, Melchionda S, et al. (2006) Pathogenetic role of the deafness-related M34 T mutation of Cx26. Hum Mol Genet 15:2569-2587. doi:10.1093/hmg/ddl184

9. Birkenhager R, Otto E, Schurmann MJ, et al. (2001) Mutation of BSND causes Bartter syndrome with sensorineural deafness and kidney failure. Nat Genet 29:310-314. doi:10.1038/ng752

10. Bockenhauer D, Feather S, Stanescu HC, et al. (2009) Epilepsy, ataxia, sensorineural deafness, tubulopathy, and KCNJ10 mutations. N Engl J Med 360:1960-1970. doi:10.1056 /NEJMoa0810276

11. Boettger T, Rust MB, Maier H, et al. (2003) Loss of K-Cl cotransporter KCC3 causes deafness, neurodegeneration and reduced seizure threshold. EMBO J 22:5422-5434. doi:10.1093 /emboj/cdg519

12. Casimiro MC, Knollmann BC, Ebert SN, et al. (2001) Targeted disruption of the Kcnq1 gene produces a mouse model of Jervell and Lange-Nielsen syndrome. Proc Natl Acad Sci U S A 98: 2526-2531. doi:10.1073/pnas.041398998 
13. Cazals Y, Bevengut M, Zanella S, et al. (2015) KCNK5 channels mostly expressed in cochlear outer sulcus cells are indispensable for hearing. Nat Commun 6:8780. doi:10.1038/ncomms 9780

14. Chan DK, Hudspeth AJ (2005) $\mathrm{Ca}^{2+}$ current-driven nonlinear amplification by the mammalian cochlea in vitro. Nat Neurosci 8: 149-155. doi:10.1038/nn1385

15. Chen J, Zhu Y, Liang C, et al. (2015) Pannexin1 channels dominate ATP release in the cochlea ensuring endocochlear potential and auditory receptor potential generation and hearing. Sci Rep 5: 10762. doi:10.1038/srep 10762

16. Cohen-Salmon M, Ott T, Michel V, et al. (2002) Targeted ablation of connexin26 in the inner ear epithelial gap junction network causes hearing impairment and cell death. Curr Biol 12:11061111

17. Cohen-Salmon M, Regnault B, Cayet N, et al. (2007) Connexin30 deficiency causes instrastrial fluid-blood barrier disruption within the cochlear stria vascularis. Proc Natl Acad Sci U S A 104:62296234. doi:10.1073/pnas.0605108104

18. Cremers WR, Bolder C, Admiraal RJ, et al. (1998) Progressive sensorineural hearing loss and a widened vestibular aqueduct in Pendred syndrome. Arch Otolaryngol Head Neck Surg 124:501-505

19. Crouch JJ, Sakaguchi N, Lytle C, et al. (1997) Immunohistochemical localization of the $\mathrm{Na}-\mathrm{K}-\mathrm{Cl}$ cotransporter $(\mathrm{NKCC} 1)$ in the gerbil inner ear. J Histochem Cytochem 45:773-778

20. Dallos P, Popper NA, Fay RR (1996) The cochlea. SpringerVerlag, New York

21. Davis H (1957) Biophysics and physiology of the inner ear. Physiol Rev 37:1-49

22. Davis H (1961) Some principles of sensory receptor action. Physiol Rev 41:391-416

23. del Castillo I, Villamar M, Moreno-Pelayo MA, et al. (2002) A deletion involving the connexin 30 gene in nonsyndromic hearing impairment. N Engl J Med 346:243-249. doi:10.1056 /NEJMoa012052

24. Delpire E, Lu J, England R, et al. (1999) Deafness and imbalance associated with inactivation of the secretory Na-K-2Cl co-transporter. Nat Genet 22:192-195. doi:10.1038/9713

25. Denoyelle F, Weil D, Maw MA, et al. (1997) Prelingual deafness: high prevalence of a $30 \mathrm{delG}$ mutation in the connexin 26 gene. Hum Mol Genet 6:2173-2177

26. Dixon MJ, Gazzard J, Chaudhry SS, et al. (1999) Mutation of the $\mathrm{Na}-\mathrm{K}-\mathrm{Cl}$ co-transporter gene Slc12a2 results in deafness in mice. Hum Mol Genet 8:1579-1584

27. Estevez R, Boettger T, Stein V, et al. (2001) Barttin is a $\mathrm{Cl}^{-}$channel beta-subunit crucial for renal $\mathrm{Cl}^{-}$reabsorption and inner ear $\mathrm{K}^{+}$ secretion. Nature 414:558-561. doi:10.1038/35107099

28. Everett LA, Belyantseva IA, Noben-Trauth K, et al. (2001) Targeted disruption of mouse Pds provides insight about the inner-ear defects encountered in Pendred syndrome. Hum Mol Genet 10:153-161

29. Everett LA, Glaser B, Beck JC, et al. (1997) Pendred syndrome is caused by mutations in a putative sulphate transporter gene (PDS. Nat Genet 17:411-422. doi:10.1038/ng1297-411

30. Everett LA, Morsli H, Wu DK, et al. (1999) Expression pattern of the mouse ortholog of the Pendred's syndrome gene (Pds) suggests a key role for pendrin in the inner ear. Proc Natl Acad Sci U S A 96:9727-9732

31. Flagella M, Clarke LL, Miller ML, et al. (1999) Mice lacking the basolateral $\mathrm{Na}-\mathrm{K}-2 \mathrm{Cl}$ cotransporter have impaired epithelial chloride secretion and are profoundly deaf. J Biol Chem 274:2694626955

32. Gerido DA, DeRosa AM, Richard G, et al. (2007) Aberrant hemichannel properties of $\mathrm{Cx} 26$ mutations causing skin disease and deafness. Am J Physiol Cell Physiol 293:C337-C345. doi:10.1152/ajpcell.00626.2006
33. Gow A, Davies C, Southwood CM, et al. (2004) Deafness in claudin 11-null mice reveals the critical contribution of basal cell tight junctions to stria vascularis function. J Neurosci 24:70517062. doi:10.1523/JNEUROSCI.1640-04.2004

34. Grifa A, Wagner CA, D'Ambrosio L, et al. (1999) Mutations in GJB6 cause nonsyndromic autosomal dominant deafness at DFNA3 locus. Nat Genet 23:16-18. doi:10.1038/12612

35. Hibino H, Horio Y, Inanobe A, et al. (1997) An ATP-dependent inwardly rectifying potassium channel, KAB-2 (Kir4. 1), in cochlear stria vascularis of inner ear: its specific subcellular localization and correlation with the formation of endocochlear potential. J Neurosci 17:4711-4721

36. Hibino H, Kurachi Y (2006) Molecular and physiological bases of the $\mathrm{K}^{+}$circulation in the mammalian inner ear. Physiology (Bethesda) 21:336-345. doi:10.1152/physiol.00023.2006

37. Hibino H, Nin F, Tsuzuki C, et al. (2010) How is the highly positive endocochlear potential formed? The specific architecture of the stria vascularis and the roles of the ion-transport apparatus. Pflugers Arch 459:521-533. doi:10.1007/s00424-009-0754-Z

38. Higashiyama K, Takeuchi S, Azuma H, et al. (2010) Ouabaininduced vacuolar formation in marginal cells in the stria vascularis is dependent on perilymphatic $\mathrm{Na}^{+}$. ORL J Otorhinolaryngol Relat Spec 71(Suppl 1):57-66. doi:10.1159/000265125

39. Higashiyama K, Takeuchi S, Azuma H, et al. (2003) Bumetanideinduced enlargement of the intercellular space in the stria vascularis critically depends on $\mathrm{Na}^{+}$transport. Hear Res 186:1-9

40. Hille B (2001) Ion channels of excitable membranes, 3rd edn. Sinauer, Sunderland, MA

41. Hinojosa R, Rodriguez-Echandia EL (1966) The fine structure of the stria vascularis of the cat inner ear. Am J Anat 118:631-663. doi:10.1002/aja.1001180218

42. Honrubia V, Ward PH (1969) Dependence of the cochlear microphonics and the summating potential on the endocochlear potential. J Acoust Soc Am 46:388-392

43. Hudspeth AJ (1989) How the ear's works work. Nature 341:397404. doi:10.1038/341397a0

44. Hudspeth AJ (2014) Integrating the active process of hair cells with cochlear function. Nat Rev Neurosci 15:600-614. doi:10.1038/nrn3786

45. Ikeda K, Morizono T (1989) Electrochemical profile for calcium ions in the stria vascularis: cellular model of calcium transport mechanism. Hear Res 40:111-116

46. Jacob S, Pienkowski M, Fridberger A (2011) The endocochlear potential alters cochlear micromechanics. Biophys J 100:25862594. doi:10.1016/j.bpj.2011.05.002

47. Jahnke K (1980) The blood-perilymph barrier. Arch Otorhinolaryngol 228:29-34

48. Jeye DA, Xiao Y-F, Sigg DC (2010) Basic cardiac electrophysiology: excitable membranes. Cardiac electrophysiology methods and models. Springer US, Boston, MA. doi:10.1007/978-1-44196658-2 2

49. Johnsen T, Larsen C, Friis J, et al. (1987) Pendred's syndrome. Acoustic, vestibular and radiological findings in 17 unrelated patients. J Laryngol Otol 101:1187-1192

50. Kamiya K, Yum SW, Kurebayashi N, et al. (2014) Assembly of the cochlear gap junction macromolecular complex requires connexin 26. J Clin Invest 124:1598-1607. doi:10.1172/JCI67621

51. Kandel RE, Schwarts HJ, Jessell MT, et al. (2013) Principles of neural science. McGraw-Hill, New York

52. Kelley PM, Abe S, Askew JW, et al. (1999) Human connexin 30 (GJB6), a candidate gene for nonsyndromic hearing loss: molecular cloning, tissue-specific expression, and assignment to chromosome 13q12. Genomics 62:172-176. doi:10.1006 /geno.1999.6002

53. Kelly JJ, Forge A, Jagger DJ (2012) Contractility in type III cochlear fibrocytes is dependent on non-muscle myosin II and 
intercellular gap junctional coupling. J Assoc Res Otolaryngol 13: 473-484. doi:10.1007/s10162-012-0322-7

54. Kelsell DP, Dunlop J, Stevens HP, et al. (1997) Connexin 26 mutations in hereditary non-syndromic sensorineural deafness. Nature 387:80-83. doi:10.1038/387080a0

55. Kikuchi T, Adams JC, Miyabe Y, et al. (2000) Potassium ion recycling pathway via gap junction systems in the mammalian cochlea and its interruption in hereditary nonsyndromic deafness. Med Electron Microsc 33:51-56. doi:10.1007/s007950000009

56. Kikuchi T, Kimura RS, Paul DL, et al. (1995) Gap junctions in the rat cochlea: immunohistochemical and ultrastructural analysis. Anat Embryol (Berl) 191:101-118

57. Kitajiri S, Miyamoto T, Mineharu A, et al. (2004) Compartmentalization established by claudin-11-based tight junctions in stria vascularis is required for hearing through generation of endocochlear potential. J Cell Sci 117:5087-5096. doi:10.1242/jcs.01393

58. Kitajiri SI, Furuse M, Morita K, et al. (2004) Expression patterns of claudins, tight junction adhesion molecules, in the inner ear. Hear Res 187:25-34

59. Konishi T, Butler RA, Fernandez C (1961) Effect of anoxia on cochlear potentials. J Acoust Soc Am 33:349-356

60. Konishi T, Hamrick PE, Walsh PJ (1978) Ion transport in guinea pig cochlea. I. Potassium and sodium transport. Acta Otolaryngol 86:22-34

61. Konishi T, Kelsey E (1973) Effect of potassium deficiency on cochlear potentials and cation contents of the endolymph. Acta Otolaryngol 76:410-418

62. Konishi T, Mendelsohn M (1970) Effect of ouabain on cochlear potentials and endolymph composition in guinea pigs. Acta Otolaryngol 69:192-199

63. Kuijpers W, Bonting SL (1970) The cochlear potentials. I. The effect of ouabain on the cochlear potentials of the guinea pig. Pflugers Arch 320:348-358

64. Kuijpers W, Bonting SL (1970) The cochlear potentials. II. The nature of the cochlear endolymphatic resting potential. Pflugers Arch 320:359-372

65. Kumar NM, Gilula NB (1996) The gap junction communication channel. Cell 84:381-388

66. Kusakari J, Rokugo M, Kambayashi J, et al. (1983) Generation mechanism of the negative endocochlear potential during early stage of anoxia. ORL J Otorhinolaryngol Relat Spec 45:195-202

67. Lautermann J, ten Cate WJ, Altenhoff P, et al. (1998) Expression of the gap-junction connexins 26 and 30 in the rat cochlea. Cell Tissue Res 294:415-420

68. Liu XZ, Xia XJ, Adams J, et al. (2001) Mutations in GJA1 (connexin 43) are associated with non-syndromic autosomal recessive deafness. Hum Mol Genet 10:2945-2951

69. Marcus DC, Demott JE, Kobayashi T, et al. (1981) Specificity of action of vanadate to the organ of Corti. Hear Res 5:231-243

70. Marcus DC, Rokugo M, Thalmann R (1985) Effects of barium and ion substitutions in artificial blood on endocochlear potential. Hear Res 17:79-86

71. Marcus DC, Wu T, Wangemann P, et al. (2002) KCNJ10 (Kir4.1) potassium channel knockout abolishes endocochlear potential. Am J Physiol Cell Physiol 282:C403-C407. doi:10.1152 /ajpcell.00312.2001

72. Melichar I, Syka J (1987) Electrophysiological measurements of the stria vascularis potentials in vivo. Hear Res 25:35-43

73. Nakazawa K, Spicer SS, Schulte BA (1995) Ultrastructural localization of Na,K-ATPase in the gerbil cochlea. J Histochem Cytochem 43:981-991

74. Nin F, Hibino H, Doi K, et al. (2008) The endocochlear potential depends on two $\mathrm{K}^{+}$diffusion potentials and an electrical barrier in the stria vascularis of the inner ear. Proc Natl Acad Sci U S A 105: 1751-1756. doi:10.1073/pnas.0711463105
75. Nin F, Hibino H, Murakami S, et al. (2012) Computational model of a circulation current that controls electrochemical properties in the mammalian cochlea. Proc Natl Acad Sci U S A 109:91919196. doi:10.1073/pnas.1120067109

76. Noble D (1984) The surprising heart: a review of recent progress in cardiac electrophysiology. J Physiol 353:1-50

77. Rickheit G, Maier H, Strenzke N, et al. (2008) Endocochlear potential depends on $\mathrm{Cl}^{-}$channels: mechanism underlying deafness in Bartter syndrome IV. EMBO J 27:2907-2917. doi:10.1038 /emboj.2008.203

78. Royaux IE, Belyantseva IA, Wu T, et al. (2003) Localization and functional studies of pendrin in the mouse inner ear provide insight about the etiology of deafness in Pendred syndrome. J Assoc Res Otolaryngol 4:394-404

79. Rozengurt N, Lopez I, Chiu CS, et al. (2003) Time course of inner ear degeneration and deafness in mice lacking the Kir4.1 potassium channel subunit. Hear Res 177:71-80

80. Russell IJ, Cody AR, Richardson GP (1986) The responses of inner and outer hair cells in the basal turn of the guinea-pig cochlea and in the mouse cochlea grown in vitro. Hear Res 22:199-216

81. Ryan AF, Watts AG (1991) Expression of mRNAs encoding alpha and beta subunit isoforms of the Na,K-ATPase in the rat cochlea. Mol Cell Neurosci 2:179-187

82. Sakagami M, Fukazawa K, Matsunaga T, et al. (1991) Cellular localization of rat Isk protein in the stria vascularis by immunohistochemical observation. Hear Res 56:168-172

83. Sakuraba M, Murata J, Teruyama R, et al. (2014) Spatiotemporal expression of TRPM4 in the mouse cochlea. J Neurosci Res 92: 1409-1418. doi:10.1002/jnr.23410

84. Salt AN, Melichar I, Thalmann R (1987) Mechanisms of endocochlear potential generation by stria vascularis. Laryngoscope 97:984-991

85. Scholl UI, Choi M, Liu T, et al. (2009) Seizures, sensorineural deafness, ataxia, mental retardation, and electrolyte imbalance (SeSAME syndrome) caused by mutations in KCNJ10. Proc Natl Acad Sci U S A 106:5842-5847. doi:10.1073 /pnas.0901749106

86. Schutz M, Auth T, Gehrt A, et al. (2011) The connexin26 S17F mouse mutant represents a model for the human hereditary keratitis-ichthyosis-deafness syndrome. Hum Mol Genet 20:2839. doi: $10.1093 / \mathrm{hmg} / \mathrm{ddq} 429$

87. Sheffield VC, Kraiem Z, Beck JC, et al. (1996) Pendred syndrome maps to chromosome 7q21-34 and is caused by an intrinsic defect in thyroid iodine organification. Nat Genet 12:424-426. doi:10.1038/ng0496-424

88. Shen Z, Marcus DC (1998) Divalent cations inhibit IsK/KvLQT1 channels in excised membrane patches of strial marginal cells. Hear Res 123:157-167

89. Shindo M, Miyamoto M, Abe N, et al. (1992) Dependence of endocochlear potential on basolateral $\mathrm{Na}^{+}$and $\mathrm{Cl}^{-}$concentration: a study using vascular and perilymph perfusion. Jpn J Physiol 42: 617-630

90. Shugyo A, Mori N, Matsunaga T (1990) A comparison of the reduction in the $\mathrm{K}^{+}$activity of the scala media produced by furosemide and ouabain. Eur Arch Otorhinolaryngol 248:79-81

91. Smith CA, Lowry OH, ML W (1954) The electrolytes of the labyrinthine fluids. Laryngoscope 64:141-153. doi:10.1288 /00005537-195403000-00001

92. Sohl G, Maxeiner S, Willecke K (2005) Expression and functions of neuronal gap junctions. Nat Rev Neurosci 6:191-200. doi: $10.1038 /$ nrn 1627

93. Stojkovic T, Latour P, Vandenberghe A, et al. (1999) Sensorineural deafness in X-linked Charcot-Marie-tooth disease with connexin 32 mutation (R142Q. Neurology 52:1010-1014 
94. Suga F, Nakashima T, JB S Jr (1970) Sodium and potassium ions in endolymph. In vivo measurements with glass microelectrodes. Arch Otolaryngol 91:37-43

95. Sunose H, Ikeda K, Saito Y, et al. (1993) Nonselective cation and $\mathrm{Cl}^{-}$channels in luminal membrane of the marginal cell. Am J Phys 265:C72-C78

96. Suzuki T, Takamatsu T, Oyamada M (2003) Expression of gap junction protein connexin 43 in the adult rat cochlea: comparison with connexin26. J Histochem Cytochem 51:903-912

97. Takeuchi S, Ando M (1998) Dye-coupling of melanocytes with endothelial cells and pericytes in the cochlea of gerbils. Cell Tissue Res 293:271-275

98. Takeuchi S, Ando M (1998) Inwardly rectifying $\mathrm{K}^{+}$currents in intermediate cells in the cochlea of gerbils: a possible contribution to the endocochlear potential. Neurosci Lett 247:175-178

99. Takeuchi S, Ando M, Irimajiri A (1997) Changes in the volume of marginal cells induced by isotonic ' $\mathrm{Cl}^{-}$depletion/restoration': involvement of the $\mathrm{Cl}^{-}$channel and $\mathrm{Na}^{+}-\mathrm{K}^{+}-\mathrm{Cl}^{-}$cotransporter. Hear Res 113:99-109

100. Takeuchi S, Ando M, Kakigi A (2000) Mechanism generating endocochlear potential: role played by intermediate cells in stria vascularis. Biophys J 79:2572-2582. doi:10.1016/S0006-3495(00)76497-6

101. Takeuchi S, Ando M, Kozakura K, et al. (1995) Ion channels in basolateral membrane of marginal cells dissociated from gerbil stria vascularis. Hear Res 83:89-100

102. Takeuchi S, Marcus DC, Wangemann P (1992) $\mathrm{Ca}^{2+}$-activated nonselective cation, maxi $\mathrm{K}^{+}$and $\mathrm{Cl}^{-}$channels in apical membrane of marginal cells of stria vascularis. Hear Res 61:86-96

103. Tasaki I, Spyropoulos CS (1959) Stria vascularis as source of endocochlear potential. J Neurophysiol 22:149-155

104. Teubner B, Michel V, Pesch J, et al. (2003) Connexin30 (Gjb6)deficiency causes severe hearing impairment and lack of endocochlear potential. Hum Mol Genet 12:13-21

105. Uetsuka S, Ogata G, Nagamori S, et al. (2015) Molecular architecture of the stria vascularis membrane transport system, which is essential for physiological functions of the mammalian cochlea. Eur J Neurosci 42:1984-2002. doi:10.1111/ejn.12973

106. Vetter DE, Mann JR, Wangemann P, et al. (1996) Inner ear defects induced by null mutation of the Isk gene. Neuron 17:1251-1264

107. Von Bekesy G (1952) Resting potentials inside the cochlear partition of the guinea pig. Nature 169:241-242

108. Wangemann P (1995) Comparison of ion transport mechanisms between vestibular dark cells and strial marginal cells. Hear Res 90:149-157
109. Wangemann $\mathrm{P}(2002) \mathrm{K}^{+}$cycling and the endocochlear potential. Hear Res 165:1-9

110. Wangemann P (2006) Supporting sensory transduction: cochlear fluid homeostasis and the endocochlear potential. J Physiol 576: 11-21. doi:10.1113/jphysiol.2006.112888

111. Wangemann P, Itza EM, Albrecht B, et al. (2004) Loss of KCNJ10 protein expression abolishes endocochlear potential and causes deafness in Pendred syndrome mouse model. BMC Med 2:30. doi:10.1186/1741-7015-2-30

112. Xia JH, Liu CY, Tang BS, et al. (1998) Mutations in the gene encoding gap junction protein beta-3 associated with autosomal dominant hearing impairment. Nat Genet 20:370-373. doi:10.1038/3845

113. Yamaguchi S, Tanimoto A, Otsuguro K, et al. (2014) Negatively charged amino acids near and in transient receptor potential (TRP) domain of TRPM4 channel are one determinant of its $\mathrm{Ca}^{2+}$ sensitivity. J Biol Chem 289:35265-35282. doi:10.1074/jbc. M114.606087

114. Yang JJ, Liao PJ, CC S, et al. (2005) Expression patterns of connexin 29 (GJE1) in mouse and rat cochlea. Biochem Biophys Res Commun 338:723-728. doi:10.1016/j. bbrc.2005.09.193

115. Yoshida T, Nin F, Murakami S, et al. (2016) The unique ion permeability profile of cochlear fibrocytes and its contribution to establishing their positive resting membrane potential. Pflugers Arch. 468:1609-1619. doi:10.1007/s00424-016-1853-2

116. Yoshida T, Nin F, Ogata G, et al. (2015) NKCCs in the fibrocytes of the spiral ligament are silent on the unidirectional $\mathrm{K}^{+}$transport that controls the electrochemical properties in the mammalian cochlea. Pflugers Arch 467:1577-1589. doi:10.1007/s00424-0141597-9

117. Zelante L, Gasparini P, Estivill X, et al. (1997) Connexin26 mutations associated with the most common form of non-syndromic neurosensory autosomal recessive deafness (DFNB1) in Mediterraneans. Hum Mol Genet 6:1605-1609

118. Zhao HB, Kikuchi T, Ngezahayo A, et al. (2006) Gap junctions and cochlear homeostasis. J Membr Biol 209:177-186. doi:10.1007/s00232-005-0832-x

119. Zhu Y, Chen J, Liang C, et al. (2015) Connexin26 (GJB2) deficiency reduces active cochlear amplification leading to late-onset hearing loss. Neuroscience 284:719-729. doi:10.1016/j. neuroscience.2014.10.061

120. Zidanic M, Brownell WE (1990) Fine structure of the intracochlear potential field. I. The silent current. Biophys J 57: 1253-1268. doi:10.1016/S0006-3495(90)82644-8 